\title{
León Ferrari: fazer comum
}

Artur de Vargas Giorgi

UNISUL

\begin{abstract}
Resumo
O ensaio retoma algumas experiências de León Ferrari (1920-2013) elaboradas em distintas linguagens no período do seu exílio em São Paulo durante as últimas ditaduras cívico-militares que tomaram o Cone Sul. Trata-se de sublinhar os aspectos não-autonômicos de seu pensamento e seus trabalhos, o que significa reafirmar uma zona de trânsito indecidível entre a ética, a política e a estética. Pensando a plasticidade das artes em estreito contato com a vida - como um contínuo desdobramento do sensível, nos mais variados materiais, meios ou suportes - o trabalho exílico de Ferrari parece acompanhar de perto algumas linhas de fuga apresentadas por contundentes críticas da filosofia política contemporânea à civilização ocidental e cristã.
\end{abstract}

Palavras-chave: León Ferrari; Exílio; Política; Impessoalidade; Comum.

\section{Resumen}

El ensayo retoma algunas experiencias de León Ferrari (1920-2013) hechas en diversos lenguajes en el período de su exilio en São Paulo durante las últimas dictaduras cívico-militares que se apropiaron del Cono Sur. Se trata de subrayar los aspectos no-autonómicos de su pensamiento y sus trabajos, es decir, de replantear una zona de tránsito indecidible entre la ética, la política y la estética. Pensando la plasticidad del arte en estrecho contacto con la vida - como un continuo desdoblamiento de lo sensible, en los más distintos materiales, medios o suportes - el trabajo exílico de Ferrari parece acompañar de cerca algunas líneas de fuga presentadas por contundentes críticas de la filosofía política contemporánea a la civilización occidental y cristiana.

Palabras clave: León Ferrari; Exilio; Política; Impersonalidad; Común. 
1. Agradeço a Fundación Augusto y León Ferrari - Arte y Acervo pela afetuosa recepção e a possibilidade de pesquisa em seu arquivo ao longo do ano de 2013.
1. Em sua extensa e diversa produção, que se situa semovente entre as inúmeras figurações da arte visual e além dela, desdobrando-se em escrita, performance, música, produção de filmes, intervenções, etc., León Ferrari mantém sobretudo uma posição crítica dos pressupostos humanistas da civilização ocidental e cristã ${ }^{1}$. A afinidade com um pensamento de esquerda, em princípio não-peronista, mas sem dúvida atento à sua razão populista, ainda que tenha impulsionado uma ativa participação nos momentos ideologicamente marcados dos anos 1960 e 1970, igualmente segue essa tendência à não-apropriação, ao desbordamento, pouco afim à rigidez doutrinária das fundações e das leituras tributárias de um crivo autonomista, não sendo redutível, portanto, aos marcos de um ideal identitário, quer seja nacionalista ou internacionalista. Não obstante, num aparente consenso, muitas críticas pluralizam o trabalho de Ferrari ao preço de o dividirem em dois polos antagônicos bem delimitados: um encerrado na abstração estética, em termos estritos; outro, na ética da participação, vale dizer, neste caso, no que se definiria por política. Conquanto distintos interesses possam, com efeito, ser ora salientados ora suavizados em seus trabalhos, e que o próprio artista tenha sustentado, durante um período, ao menos, a demarcação desses limites, uma análise atenta à ficção que León Ferrari mobiliza expõe o aspecto notadamente não-autonomista de sua produção, endereçada aos contatos, ao comum. De acordo com essa leitura, retrospectivamente, desde as primeiras experiências, o que sobressai é um exercício constante de produção de imagens plurais - e não a sua polêmica iconoclastia, portanto -, na medida em que seu repertório de procedimentos, reativando o dadaísmo, não cessa de aproximar registros - tempos, espaços, pensamentos - dissímeis, numa compreensão bem mais inclusiva, irônica, lúdica, mesmo tátil, do estético, sendo indissociável, então, de uma potência ética. Durante a última ditadura argentina, quando decidiu deixar Buenos Aires e o país para seguir com sua família para São Paulo, onde permaneceu de 1976 a 1984, Ferrari dedicou-se a um intenso experimentalismo (técnicas, suportes, etc.), expondo e travando contatos com uma ampla rede de artistas e críticos latino-americanos. A produção desse período conturbado e sem dúvida incontornável desdobra-se como uma série de modulações de um mesmo aspecto a-fundacional, sempre reincidente e aberto a notáveis articulações com diversas forças textuais e pictóricas. $\mathrm{O}$ exílio que assim se apresenta não poderia não ser, também ele, dado à abertura, neutralizador das naturalizações e suspensivo das fronteiras dadas a priori.

2. O Centro Cultural de la Memoria Haroldo Conti, inaugurado em 2008 num dos prédios da antiga Escuela de Mecánica de 
la Armada (ESMA), é hoje uma das várias instituições que em espaços públicos buscam responder ao passado recente argentino. Localizado onde funcionou, durante a última ditadura militar, o que talvez tenha sido o mais emblemático centro de detenção, tortura e extermínio da América Latina, o Centro Cultural tem como objetivo ser um "espacio de difusión y promoción de la cultura y los derechos humanos" 2 . Em sua página de internet há uma síntese desse programa compartilhado com outros espaços semelhantes, não só na Argentina, na medida em que se baseia num aparente consenso - um discurso tão cristalizado quanto sujeito a disputas ${ }^{3}$ - sobre a necessidade de fazer ressoar eventos traumáticos da história: "Transformar en un espacio abierto a la comunidad lo que antes fuera un sitio emblemático de privación, exclusión y muerte es el mayor compromiso y desafío para contribuir a la construcción de memoria, verdad y justicia"4. Não deixa de ser significativo que, no horizonte de justiça a ser construído, também apareçam como construções necessárias a memória e a verdade, noções que desse modo se afastam da lógica da presença e da percepção fenomenológica; desnaturalizadas, se deslocam para um a posteriori contingencial. Passa-se da imediata relação com um passado já dado e reconhecível como tal para a constante mediação de demandas ou topoi flutuantes, que não escapam da ambivalência que diz respeito às semânticas da abertura e da comunidade, com suas inúmeras aporias. Nesse sentido, o tópico dos direitos humanos reaparece como um nó semântico, com o qual tais ambivalências se mostram de maneira acentuada.

$\mathrm{Na}$ Argentina, os noticiários da manhã de quinta-feira, dia 25 de julho de 2013, anunciavam que, durante aquela madrugada, aos 92 anos, León Ferrari havia falecido. Assim, coube ao grande vão térreo do Centro Haroldo Conti ser o espaço que receberia a última exposição em vida de Ferrari, realizada entre março e maio desse ano, na qual também figuravam alguns trabalhos do seu então assistente, Yaya Firpo. Chamada Taller Ferrari, a mostra tinha como eixo curatorial acercar-se do espaço de trabalho do artista, do contexto de experimentação, levando ao ambiente expositivo a possibilidade de um contato não somente com as já definidas "obras", mas também com o contínuo processo criativo, por meio da "reinstalación de múltiples y significativos elementos provenientes de su taller, que constituyen la materia prima de su trabajo" ${ }^{5}$. Sem insistir na acentuada distância entre a proposta da curadoria e a efetiva colocação em cena da exposição ${ }^{6}$, é possível afirmar, ainda assim, que com os elementos escolhidos para a mostra mais uma vez se evidenciava como a pluralidade dos trabalhos (técnicas, suportes, materiais, núcleos de sentido, etc.) e dos interesses (religião, violência, estética, ética, música, erotismo, literatura, história, etc.) de
2. Página da web do Centro Cultural de la Memoria Haroldo Conti. Disponível no seguinte endereço: <http://conti. derhuman.jus.gov.ar/areas/ institucional/institucional.shtml>. Acesso em: 19 abril de 2017.

3. "Durante las décadas del ochenta y el noventa, la actitud del Estado nacional fue débil y ambigua: más allá de las condenas en juicios, la ESMA continuó desempeñando sus funciones militares. En el marco de su política hacia el pasado reciente, el presidente Carlos Menem, en enero de 1998, propuso demoler las instalaciones de la ESMA para crear en ese lugar un espacio verde como 'símbolo de la unión nacional', iniciativa frenada por la oposición del movimiento de derechos humanos y una medida judicial. / En febrero de 2004, el presidente Néstor Kirchner anunció su intención de allanar el camino para que en la ESMA se construyera un Museo de la Memoria. Lo hizo en un contexto de fuerte presencia del tema de la memoria de la dictadura en el espacio público [...]. / Desde el año 2004, cuando se inició el proceso de constitución del Espacio, se produjo un notable deslizamiento en las discusiones: inicialmente ancladas en la cuestión de la memoria, y específicamente acerca de qué tipo de museo construir en la ESMA, derivaron en disputas acerca de la interpretación histórica al pasado reciente. / El fuerte sesgo 'setentista' que tanto se les adjudica como asumen los gobiernos kirchneristas ha influido en 
esta dinámica, y estos rasgos encontraron en las discusiones acerca de la ESMA un espacio privilegiado". LORENZ, Federico. "La ESMA, un espacio en construcción: Estado y actores sociales en un sitio de memoria", 2010, p. 165-167. Uma discussão sobre os usos do passado e da memória na contemporaneidade argentina, como crítica dos privilégios do relato subjetivo - em primeira pessoa - e do reconhecimento da experiência pessoal como argumento de verdade, pode ser encontrada em SARLO, Beatriz. Tiempo pasado, 2005. Um exercício comparativo de dois espaços de memória pode ser visto em BURUCÚA, José Emilio; KWIATKOWSKI, Nicolás. "Un terror, dos lugares, ¿qué memoria? Reflexiones acerca de dos espacios para la memoria en el Cono Sur". Caiana, 2012, p. 1-9.

4. Página do Centro Cultural de la Memoria Haroldo Conti, op. cit.

5. Segundo texto de apresentação de Andrés Duprat, curador da exposição, afixado no local.

6. Para mencionar apenas um ponto em que se mostra essa distância entre proposta e execução, basta pensar na desproporção que há entre as dimensões do taller de Ferrari e as do Centro Haroldo Conti; e a esse descompasso entre as escalas físicas se somaria uma divergência no modo de pensar e ocupar o espaço: se no estúdio os elementos se movimentavam em função do pensamento, do experimento, da montagem, da superposição e do acúmulo, da tentativa e do erro, em função da desordem, enfim, na exposição, ao contrário, eles se cristalizaram num já-acabado quase linear, às vezes em séries, em nichos, organizados num todo que enfraqueceu muito a potência do que é processo.
Ferrari na verdade compõe uma singular trama, absolutamente complexa, que entre uma dobra e outra vai apresentando seus diferentes aspectos. Mas desse modo, isto é, com a atenção voltada também para o espaço da exposição e o contexto que ele imediatamente faz ressoar - um campo amplificado de forças contrapostas, em tudo oposto à suposta esfera imune do cubo branco - seria possível enfatizar certos trabalhos que estabelecem uma relação singular com a ditadura e sua violência. Não porque sejam trabalhos que simplesmente a transformam em tema ou objeto sobre o qual incide a crítica, desde sempre contrária; nem porque foram produzidos apesar dela, e sim porque são trabalhos que surgiram com ela: em certo sentido, em razão da ditadura, como um excesso não calculado ou um resto sensível, mas por isso mesmo não pacífico, resistente, do que parece ser a sua lógica. Nesses trabalhos o que se vê como saída é uma espécie de suspensão: se o projeto "político" ditatorial se exercia - ou, mais precisamente: se executava - por meio de uma polícia imunitária de fundo personalista, nos trabalhos do exílio - em trabalhos exílicos - pode-se ler a politicidade do impessoal.

3. O pensamento da impessoalidade encontra na América Latina figurações ineludíveis. Dir-se-ia, nesse sentido, que a escritura indígena, no que se sabe dela, nos seus mais distintos suportes e meios, não faria mais que apresentar alguns dos traços mais potentes dessa ética, in-operante de acordo com as muitas modalizações possíveis de um pensamento sobre o comum ou o neutro que situa numa zona de indecisão as consensuais categorias do logos ocidental. Mas também a literatura moderna e as experiências das vanguardas e das pós-vanguardas puderam elaborar suas inflexões e diferimentos de um caráter terceiro que, sendo suspensivo da dialogia e da dialética, é desse modo capaz de apontar para o jogo contingencial com a linguagem, reforçando uma espécie de potência dis-positiva da técnica. "Carpentier, Guimarães Rosa, los modernos escritores latinoamericanos, como sabemos, estaban más empeñados en una lógica de la situación que en una simple oposición diacrítica", escreve Raul Antelo $^{7}$. O mesmo interesse que parecia mover Luigi Pareyson, diretor da Facultad de Filosofía da Universidad Nacional de Cuyo, em Mendoza, com ativa participação no Congreso de Filosofía de 1949; congresso que, ao pé da Cordilheira dos Andes, diante do deserto, situaria a importância da discussão a respeito da noção de pessoa apenas um ano depois da Declaração Universal dos Direitos Humanos, documento que oscila, categorialmente, entre "Todos los seres humanos" (Artigo 1) e "Toda persona" (Artigo 2) quando da definição dos direitos e liberdades proclamados, mas dirigindo-se, claro está, àqueles "dotados como están de razón y conciencia" (Artigo 1) ${ }^{8}$. Com 
efeito, o conceito foi debatido a partir de várias perspectivas: de uma positivação fenômeno-ontológica da pessoa ${ }^{9}$, passando por uma definição do seu "ethos" próprio ${ }^{10}$, por um posicionamento reticente quanto ao primado do espiritual - em detrimento do corpóreo ou do anímico - em sua identificação ${ }^{11}$, até uma proposição compósita, afirmativa em razão justamente do seu aspecto ambivalente, como a de Luigi Pareyson:

Iniciativa parece ser a situación como actividad a pasividad. La situación es pasividad: no dependen de mí mi colocación espacial y temporal, mi estado actual a pesar de que resulte de mis libres actos, la espontaneidad de mis dones naturales, que constituyen mi naturaleza: necesidad a la que estoy sujeto. Pero aún la iniciativa, en su estructura, como exigencia y evaluación, es naturaleza y necesidad: como exigencia es obligación de operar y ley del operar, y yo no puedo dejar de operar, ni tampoco substraerme al reconocimiento del carácter perentorio de la ley; como evaluación es aprecio y juicio, y yo no puedo dejar de apreciar, ni tampoco substraerme a la inevitable presencia, en cada uno de mis actos, del juicio que determina su valor, y que yo mismo doy, quiéralo o no. Como tengo una situación, un estado, un don, así tengo el poder de la libertad y la facultad de juzgar: este tener no soy yo que me lo di, mas lo recibí: posesión acogida, naturaleza recibida, pasividad del yo. Pero en el hombre no hay pasividad que no se resuelva en actividad. Los datos de la situación no son por sí mismos obstáculos e impedimentos, pero pueden llegar a serlo en aquella reacción mía personal frente a ellos, la cual puede también resolverlos en ocasiones y oportunidades: en todo caso se trata de pasividad que se convierte en actividad; de determinación inicial que se muda en libertad final. Además la libertad y el juicio, como poder y facultad, son dados, más aún impuestos al hombre, pero en su uso y ejercicio dependen integralmente del hombre. Que yo sea libre en disponer de mí mismo y juez de mi experiencia no depende de mí, pero yo soy el autor de cada uno de mis actos y de toda mi experiencia. Mi naturaleza de ser libre y juez se hace acto, acto de un yo que es libre y juzga: mi pasividad se vuelve actividad. [...] las personas que uno quisiera ser son muchas, y sucesivas y sustituibles, de modo que en este sentido la persona llega a ser verdaderamente la 'máscara', es decir el carácter típico que se asume o se depone o se sustituye, como ideal o tarea. Cada una de estas máscaras tiene una interna coherencia lógica, la cual de necesidad lógica se muda en necesidad física y aún moral, después del libre acto con el que se la asume como tarea. ${ }^{12}$

A estratégia de Pareyson parece ser a de expor o artifício, com o que o poder de captura do dispositivo deriva numa potência de suspensão da positividade: a pessoa, então, como um dis-positivo. Uma posição que afasta Pareyson das demais elaborações do conceito, filosóficas ou eminentemente políticas, nas
Um dia após o falecimento de Ferrari, num pequeno texto de Andrea Giunta que circulou on-line, há uma passagem com a qual se pode reafirmar a distância em questão: "El taller de León era una usina de ideas, un abroquelamiento barroco de objetos y de obras entre las que no se podía caminar. En los años noventa León tenía un taller frente a la central de Policía en el que, literalmente, un día ya no se pudo entrar. Estaba completamente lleno de obra. León trabajaba en un espacio mínimo, rodeado de sus objetos y de sus dibujos. Nos sentábamos a conversar casi sin poder movernos, completamente rodeados de dibujos, cucarachas de plástico, flores, cocinitas, licuadoras, sartenes".

7. ANTELO, Raul. "El futuro fabuloso, la forma formante y el pozo de Babel", 2014, p. 35.

8. As muitas traduções da Declaração Universal dos Direitos Humanos, de 1948, podem ser conferidas em: $<$ http://www.ohchr.org/EN/ UDHR/Pages/UDHRIndex. aspx>. Acesso em: 19 abril 2017.

9. " $\mathrm{Si}$, pues, la persona se constituye especificamente tal por esta perfección de su intencionalidad cognoscitiva, que la pone frente a la trascendencia del ser (objeto) y en posesión consciente de su propio ser inmanente (sujeto), y en dominio activo de su actividad por la libertad, y tales notas tienen su raíz ontológica y constitutivo esencial en la espiritualidad, síguese que el constitutivo o diferencia especifica de la persona es la espiritualidad. La nota específica, pues, de la persona, la que la contrae y distingue esencialmente de la noción genérica de supósito es la espiritualidad o, como decían los antiguos atendiendo a la 
primera manifestación de esta espiritualidad, la racionalidad en el amplio sentido de intelectualidad". DERISI, Octavio Nicolás. "Fenomenología y ontología de la persona". Actas del Primer Congreso Nacional de Filosofía [1949], 1950, p. 299.

10. "La personalidad es la esencia íntima del hombre individual abierta por antonomasia al mundo. No solamente en virtud de las condiciones de su ser, sino más aún por el contenido significativo de su existencia, el 'ethos' y el contenido de valor suyos, ella se encuentra incorporada a su mundo circundante, al mundo espiritualcorporal del hombre. Y como ya el ser de la mera persona traza alrededor de sí un círculo de pertenencia, una esfera de poder de influencia que lleva el sello de propiedad de la persona, así también lo hace la personalidad". HARTMANN, Nicolai. "El 'ethos' de la personalidad". Actas del Primer Congreso Nacional de Filosofía [1949], 1950, p. 313.

11. "[...] la unicidad de cada ser humano no se debe exclusivamente a la persona. Tan única como ésta es la unidad anímica subpersonal del individuo y hasta el ser de su organismo. Esto nos lleva a señalar un extremo discutible, cual es el aserto de que sólo con el espíritu, sin nada previo, nace la persona. El examen imparcial de la realidad pone de manifiesto que hay cierta continuidad en el proceso diferenciador que va desde la cosa hasta la persona, pasando por el ser vivo y el individuo anímico. Esta gradación -que no se opone a la diferencia fundamental- es particularmente manifiesta tanto entre lo orgánico y lo anímico, cuanto entre lo anímico y lo espiritual. [...] No está probado quais, grosso modo, a pessoa é um suplemento ao dado meramente corpóreo da vida, mas como um plus de bios, isto é, como evolução de uma capacidade voluntariosa, baseada na racionalização e na autodeterminação, que tem como efeito a objetivação da vida e, sobretudo, da animalidade, o que destinaria a pessoa a um plano de "transcendência" em que o homem, não mais como animal, e sim, finalmente, como "pessoa humana", encontraria seu ideal mais acabado. Daí o paradoxo dessa lógica que afirma a unidade pela disjunção: o direito bumano se generaliza quando consagrado às pessoas. Com os textos mendozinos ${ }^{13}$ e outros posteriores, Raul Antelo compõe um cenário exílico: onde se desdobraria um pensamento latino-americano afim ao do filósofo italiano:

En esa realización imposible de la metafísica, en esa irrupción del escaton en el propio tiempo de la experiencia y en ese consecuente advenimiento de la metahistoria en el seno mismo de la historia [...], que, como muestra Roberto Esposito, serviría para separar personalidad de subjetividad, Pareyson retomaba lo que Macedonio Fernández ensayara mucho antes, primero con su tesis de abogacía (De las personas, 1897), simultáneamente, en algunos artículos para La Montaña, la revista de Lugones e Ingenieros, como "La desherencia" (1897), donde augura que el siglo que suprimirá la herencia empezará por no heredar casi nada y, en consecuencia, en sus ficciones, que desconstruyen, avant la lettre, el ciclo de ensayos de interpretación nacional de la persona, de la personalidad nacional, en que figuran, entre tantísimos otros, la Radiografía de la pampa, Raízes do Brasil o el Contrapunteo cubano del tabaco y el aqúcar. Contra la hipóstasis del Autor continuo (la persona), Macedonio inventa el lector salteado, el no existente caballero (lo fragmentario, los significantes vacíos). De algún modo, la desherencia macedoniana se leería, después, en Luigi Pareyson y, gracias a él, en cierta filosofía italiana contemporánea, como en Cacciari o Esposito.

En efecto, Pareyson elabora, en sus años mendocinos, un existencialismo renovado, un personalismo ontológico, que se sistematizaría, al regresar a Italia, en Existencia y persona (1950). Dándole la espalda a Croce, o sea, al liberalismo vivo aún en Gramsci, Pareyson parte de una filosofía de la persona para proponer una metafísica de la forma, cuya expresión teórica más acabada se leerá en Estetica. Teoria della formativitá (1954). ${ }^{14}$

Em Roberto Esposito podem ser vistos, portanto, os efeitos de uma série de proposições in-operantes que eram encenadas, já antes, em distintas situações latino-americanas. Por uma sorte de biopolítica afirmativa da vida e dando seguimento às notáveis análises das categorias que fundamentam a política policial do Ocidente cristão - política caracterizada por sua maquinaria imunitária -, Esposito repõe a noção de pessoa, traçando 
inflexões - teológicas, filosóficas, legais, bioéticas - com as quais se pode ver que o princípio de uma vida dupla se transfere do indivíduo vivente para a espécie humana em seu conjunto; e isso tanto nos marcos ideológicos do racismo nazista quanto, finda a guerra, e sobre os restos desse último avatar de uma antiquíssima razão eugênica ${ }^{15}$, no relançamento global da categoria, como forma de encontrar resposta para o que é dito em seu próprio nome. "Uno de estos nudos antinómicos entre lo arcaico y lo contemporáneo, sin duda el más relevante”, escreve ele, "es precisamente [...] el 'dispositivo' de la persona", destacando "su rol performativo, esto es, productor de efectos reales"16. Segundo o autor, tal dispositivo se baseia na separação "presupuesta, y recurrente una y otra vez, entre persona como entidad artificial y hombre como ser natural para el que puede ser apropiado o no un estatus personal" 17 . Pessoa "es aquello que en el cuerpo es más que el cuerpo"18:

[...] nunca reducible por completo al sustrato biológico del sujeto al que designa; adquiere su significado más pleno, justamente, en una suerte de excedente, de carácter espiritual o moral, que la hace algo más que ese sustrato biológico, sin coincidir tampoco del todo con el individuo autosuficiente de la tradición liberal. ${ }^{19}$

Ao traçar o percurso da categoria no pensamento político moderno, Esposito mostra que, ao contrário do que faz crer o discurso humanitário - seja remetendo à semântica da cidadania nos marcos da trindade revolucionária francesa ou à reivindicação da "pessoa humana" na Declaração Universal dos Diretos Humanos -, essa noção não livra, não irmana e nem iguala os homens em justiça, uma vez que ela está na própria base do que os diferencia não apenas uns dos outros, mas também de si mesmos. Pessoa é aquilo que produz uma diferença excludente (e que só se produz por essa exclusão); uma distinção valorativa, entre os seres e em cada ser, que, sendo política e jurídica, é simultaneamente vital: é aquilo que em seus efeitos permite que sobre a vida humana incida um poder decisório, dotado de razão ou espírito - dotado de direito -, que tanto pode legitimar a condição da vida qualificada, sobreposta à animalidade, como pode condenar a existência, retirando-se e deixando exposta nada mais que essa vida qualquer, reduzida a uma coisa, "mero" resto biológico. A expressão "pessoa humana", distanciando-se assim do que seria um excesso retórico, marca bem o papel do excedente e o sentido a ser cobrado com a ameaçadora e sempre possível disjunção dos termos.

Exilados, desaparecidos, sequestrados, torturados, assassinados são desse modo sujeitos: vidas que sofrem os efeitos de uma cisão análoga e, no limite, tributária daquela operada com que la identidad de la persona dependa exclusivamente del espíritu. Por el contrario, parece que desempeñan un papel importante en su conservación condiciones comunes con el despertar del yo y con la conciencia del yo, entre las cuales sólo señalaremos una de orden psicofisiológico: las sensaciones de nuestro propio cuerpo, que, repetidas, condicionan una estructura de impresiones privilegiadas, promotora y renovadora del discernimiento y la convicción de nuestra íntima permanencia. A este propósito, y en relación con nuestro asunto, confesamos que cada día la experiencia nos inclina más y más a dar importancia al cuerpo -al cuerpo vivo, que San Pablo pedía a los hombres que lo ofrecieran a Dios como hostia santa, y que Nietzsche lo identifica con nuestro Selbst- la experiencia nos inclina, digo, a darle importancia en asuntos que, según las ideas en boga, dependen sólo del espíritu". DELGADO, Honorio. "La persona humana desde el punto de vista psicológico". Actas del Primer Congreso Nacional de Filosofía [1949], 1950, p. $274 / 275-276$.

12. PAREYSON, Luigi. "Sobre el concepto de persona". Actas del Primer Congreso Nacional de Filosofía [1949], 1950, p. 10791080/1081.

13. O outro texto lido pelo filósofo foi "La filosofía italiana contemporánea". Actas del Primer Congreso Nacional de Filosofía. Op. cit., tomo I, p. 480-492.

14. ANTELO, Raul. "El futuro fabuloso, la forma formante y el pozo de Babel”, 2014, p. 43.

15. Cf. ROMANDINI, Fabián

Ludueña. $A$ comunidade dos

espectros, 2012. 
16. ESPOSITO, Roberto. Tercera persona, 2009, p. 2021. Mantenho a tradução castelhana, já que o texto ainda não encontra versão portuguesa diretamente do italiano.

17. "Esta separación sistemática no es otra cosa que la primera y originaria distinción entre categorías abstractas, pero concretísimas en cuanto a los procedimientos de exclusión que originan, plasmadas por el derecho romano". Ibidem, p. 20-21.

18. Ibidem, p. 23.

19. Ibidem, p. 106.

20. A entrevista em questão pode ser vista na página: $<$ http:/ /www.infobae. com/2013/05/17/711088videla-y-su-historica-explicacionlos-desaparecidos/>. Acesso em: 19 abril 2017.

21. ESPOSITO, Roberto. Tercera persona, 2009, p. 29. a arcaica noção de pessoa, na medida em que esta, como outros dispositivos implicados numa forçosa separação de bíos e zoé, serve para sancionar uma objetivação: para admitir ou confirmar a superioridade de um poder, de uma lógica imunitária; e igualmente para aplicar a devida punição àqueles que não devem participar dessa forma apropriadora do comum, o que então acontece por meio da desaplicação do direito. São por isso sujeitos que, em falta ou destituídos de "personalidade", de um suplemento para o humano, seguem, não obstante, sujeitados como vida sem forma, sem máscara, como matéria vivente ou como homens, apenas, capturados pelo componente pessoal. Não à toa, essa vida sem forma, que assoma como complementaridade contrastiva à vida qualificada, parece referir-se muito bem aos milhares de desaparecidos da última ditadura militar argentina, e isso segundo definição do então ditador Jorge Rafael Videla, em entrevista de 1979, após a visita da Comissão Interamericana de Direitos Humanos ao país:

La Argentina atiende a los Derechos Humanos en esa omnicomprensión que el término Derechos Humanos significa [...]. Frente al desaparecido, en tanto esté como tal, es una incógnita el desaparecido. Si el hombre apareciera, bueno, tendría un tratamiento $\mathrm{X}, \mathrm{y}$ si la aparición se convirtiera en certeza de su fallecimiento, tiene un tratamiento Z. Pero mientras sea desaparecido no puede tener ningún tratamiento especial, es una incógnita, es un desaparecido, no tiene entidad, no está... ni muerto ni vivo, está desaparecido. ${ }^{20}$

Poderia ser dito, em suma, que exilados, desaparecidos, sequestrados, torturados são sujeitos pessoais: sujeitos à objetivação; sujeitos que se mostram apenas por meio da própria reificação, ao mesmo tempo em que mostram e confirmam, por essa diferença de valor e pela separação, a maquinaria à qual estão sujeitos.

Como suspender o funcionamento desse dispositivo excludente, se a mera oposição - ser "anti” ou "contra" pessoa - claramente resulta em ser o seu oposto necessário, em ser uma espécie de complemento fundamental ou constitutivo, por assim dizer? Esposito apresenta a leitura de autores que elaboraram de diversos modos um pensamento do impessoal ou da figura terceira da terceira pessoa: Simone Weil, Benveniste, Kojève, Jankélévitch, Levinas, Blanchot, Foucault, Deleuze. Não obstante, como já visto, numa série mais ampla é possível acrescentar a esses nomes, outros; e talvez seja possível encontrar indícios dessas "diversas filosofías de lo impersonal" 21 em trabalhos não propriamente filosóficos. Nesse sentido, parece que a intensa experimentação de León Ferrari durante o exílio bloqueia o efeito de reificação da semântica da pessoa; quer dizer, "no es su 
negación frontal -como lo sería una filosofía de la antipersona-, sino su alteración, su extraversión hacia una exterioridad que pone en tela de juicio e invierte su significado prevaleciente"22, o que Daniel Link chamou de "experiencia exterior"23.

4. De São Vicente, linha litorânea que um dia seria delegada aos diletantes - quando não aos delirantes - aventureiros, e não aos centrados trabalhadores, partira para a volta a Europa, num barco português rumo a Lisboa (e daí a Sevilha, Cádiz e, finalmente, Antuérpia), Ulrich Schmidel, em junho de 1553, depois de dezoito anos de vida e mortes nas Índias Ocidentais, depois das crônicas da desastrada primeira fundação de Buenos Aires ${ }^{24}$. São Vicente, linha-delírio onde, na mesma época, encontrara-se quase perdido Hans Staden, jovem aventureiro alemão com vinte e poucos anos de idade, náufrago de navio espanhol, já em sua segunda viagem ao Novo Mundo, quando então, capturado por índios tamoios, por pouco não fora comido. Séculos depois, o exílio de León Ferrari em São Paulo iniciar-se-ia igualmente excêntrico, pelos limites da/do capital (onde a cabeça delira), junto às margens dessa mesma linha oceânica, onde a cada vez recomeçam as ambivalências da abertura e que, bem situada, também leva nome de santo: São Vicente é igualmente a cidade que acolhe Ferrari e sua família (com exceção do filho Ariel, morto pela ditadura) no final de 1976. São Vicente que, como se vê, ocupa um lugar que poderia ser dito fundacional na história do Brasil, como vila litorânea pioneiramente organizada, logo batizada em homenagem ao diácono Vicente de Zaragoza, cristão martirizado em Valência por ordens do pró-cônsul romano Daciano, no início do século IV. São Vicente, este, que, segundo sua hagiografia ${ }^{25}$, após a reconquista de Lisboa aos mouros e o traslado de suas relíquias para esta cidade, em 1173, quando são depositadas no presbitério da catedral, passa a ser seu padroeiro, tendo seus atributos prolificamente expostos na iconografia lisboeta: a dalmática e o evangelho da pregação; o cavalete, a grelha e o garfo de ferro do martírio; a mó e, principalmente, os corvos e o barco, relacionados ao corpo que, mesmo destroçado e morto, teria resistido em desfazer-se por completo e desaparecer. Com o que se pode afirmar: se, segundo sua etimologia, exilar-se é "sair para fora", este "fora" deve inevitavelmente ser considerado também sob uma perspectiva que postula sua mais profunda imersão nos próprios fundamentos da civilização ocidental e cristã, do que redundaria uma zona de indiscernibilidade fundamental entre exílio e política ${ }^{26}$. Por essa obscuridade que se espraia e permeia as dobras do tempo e da linguagem, mas com a qual é possível ler os restos da violência e as marcas do poder, exilar-se seria assim arriscar-se a sair para onde, a rigor, não haveria saída.
22. Ibidem, p. 27.

23. Cf. LINK, Daniel. "León Ferrari: la experiencia exterior", 2012.

\section{Cf. GIORGI, Artur de} Vargas. "A primeira fundação de Buenos Aires, ainda". PÓS, 2016, p. 62-73.

\section{Cf. SANTAMARÍA,}

Eduardo Carrero. "La catedral, el santo y el rey. Alfonso IV de Portugal, san Vicente mártir y la capilla mayor de la sé de Lisboa", 2008, p. 73-92.

\section{Cf. ROMANDINI, Fabián}

Ludueña. "Ultrahistoria del exilio: una genealogía de la Modernidad", 2011. E, a esse respeito, ainda: "De certa forma, os anjos, verdadeiros espectros rebeldes, declaram uma espécie de herem voluntário que os separa da comunidade sagrada de pertença e, portanto, são os primeiros proscritos e os exilados originários da hierarquia do governo angélico. Por isso também o exílio é a categoria política originária, e toda política 
é co-originariamente exílica. O mundo da política humana é o lugar do exílio dos anjos caídos. [...] Ao sacrificar a si mesmo, Jesus tenta reparar a cisão originária e, no mesmo gesto, santificar, sacralizara a totalidade do mundo. Se for assim, o exilio, como forma de afastamento do poder soberano de Deus se torna de agora em diante inviável como atitude política, dado que a crucificação faz com que, a partir dela, todo exílio seja impossível, já que não há território fora dos domínios de Deus. Mesmo o Inferno, figura suprema da profanação, é só um modo de seguir sob as hierarquias diabólicas dos anjos, só que agora sob a forma da punição perpétua. Jesus absorve em si toda separação, liquida todo exílio, dirime toda cisão. A partir de sua morte, todo o mundo não cessará de sacralizarse e toda profanação só poderá reforçar o novo poder divino". Idem. A comunidade dos espectros, 2012, p. 121/126.
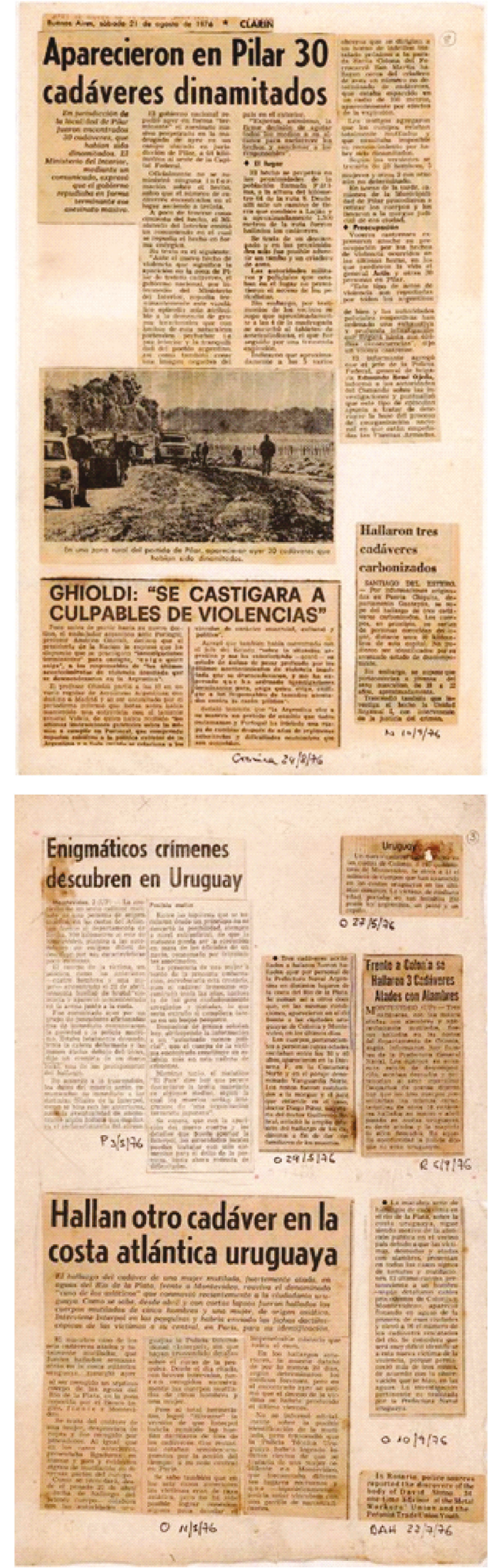

Fig. 1: León Ferrari, Nosotros no sabíamos, 1976 (páginas 8 e 3).

Fundación Augusto y León Ferrari Arte y Acervo. 
O exílio de León Ferrari passa por esse espaço temporal, imagético e linguístico onde se delineia uma extensão dos limites e da captura; mas, ao mesmo tempo, onde esse limite se faz acesso ou limiar a uma orla de sentido, que se abre. Se de uma Buenos Aires clausurada ele "sai" para essa universalidade do econômico e do policial, também nessa saída encontra a possibilidade de um uso afirmativo dos dispositivos e de uma resistência que não se esgota ou se entrega em ser apenas contrária. Ou seja, por certo não se trata mais de seguir o projeto revolucionário alentado por diversos artistas, incluindo Ferrari, ao final do itinerário da década de 1960, o que culminou, sobretudo após Tucumán Arde, na opção de alguns pela clandestinidade e a luta armada, como forma de cumprir o verdadeiro papel da vanguarda. A partir de maio, no ano do golpe, e até poucos dias antes de deixar o país, em outubro, Ferrari recolheu dos diários notícias sobre corpos que apareciam nas margens do Rio da Prata, mortos crivados em diferentes bairros de Buenos Aires e outras províncias argentinas, a desaparição em Buenos Aires de Juan José Torres, ex-presidente da Bolívia, crianças desaparecidas. Recortava e colava as matérias da imprensa oficial em grandes folhas, indicando a data e o periódico ${ }^{27}$. Em São Paulo esse material seria editado com o título de Nosotros no sabíamos, fazendo eco à frase com que um setor da sociedade argentina tentava explicar sua apatia frente aos crimes do Estado castrense; crimes que, não obstante, podiam ser facilmente constatados por meio dessas mesmas notícias, publicadas ou porque burlavam a censura ou porque correspondiam à estratégia dos militares para disseminar uma atmosfera de terror: afinal tratava-se de uma ameaça que, exatamente por ser pouco precisa em relação a quem se dirigia, podia estar dirigida a qualquer um.

Nosotros no sabiamos: a força da repetição ${ }^{28}$ permite a exposição do caráter pessoal que regula também a primeira pessoa do plural: em nós, na verdade, há sempre a predominância do $e$, na medida em que só pode haver nós a partir de um eu que deve sujeitar o não-eu - seja ele qual for - na formação dessa espécie particular de totalidade, nunca equivalente. Essa formulação de Benveniste $^{29}$ é retomada por Esposito, que em sua leitura chama atenção para a dilatação dos rasgos identitários do eu que há nessa pessoa estendida pelo plural, reafirmando que, de outro modo, "la única que tiene un plural -incluso cuando es singular, o justamente en cuanto tal- es la tercera persona, pero precisamente porque, en sentido estricto, es no-persona"30. Ou seja: se "el ámbito de sentido del yo y del tú es la presencia eterna -redoblada en la representación que un término produce en el otro-, el de la tercera persona es la ausencia"31, como no âmbito de um acontecimento sem sujeito. Nosotros no sabiamos: no pretenso enunciado comum se ouve o discurso da propriedade.
27. Cf. página introdutória da edição de 1992 de Nosotros no sabiamos. Buenos Aires: Fundación Augusto y León Ferrari Arte y Acervo, e cronologia em GIUNTA, Andrea (Ed.). León Ferrari: retrospectiva, 2006.

28. "El artista que multiplica su obra, ya sea a partir del oficio demorado y meticuloso del grabador o bien desde la posibilidad de multiplicación mecánica inmediata que habilitó la fotocopia, repone el sentido político de la repetición. A León Ferrari le cuestionaban que siempre decía lo mismo. Afirmaba que lo hacía porque las cosas que denunciaba seguían sucediendo. Repetir es resistir. Es convertir el mensaje en un repiqueteo, una metralla. El sonido y la imagen repetidos, insistidos. La monotonía, las repeticiones con desvíos mínimos, la demora de las imágenes, la actualización de archivos en los que éstas reiteran el mismo esquema, son un rasgo recurrente en el arte contemporáneo”. GIUNTA, Andrea ¿Cuándo empieza el arte contemporáneo?, 2014, p. 35 .

29. Cf. BENVENISTE, Émile. "Estrutura das relações de pessoa no verbo", 1976, p. 256.

30. ESPOSITO, Roberto. Tercera persona, 2009, p. 157.

31. Ibidem, p. 155. 
E assim, com a exposição desse caráter pessoal que submete os sintagmas, o que também se mostra com a montagem de Ferrari é uma incontornável antinomia, porquanto não saber é uma instância que não participa do paradigma da pessoa; é uma experiência, por assim dizer, propriamente impessoal ou acéfala, no preciso sentido de que depende da ausência, da suspensão da dimensão racional, dialógica e hierárquica implicada na concepção apropriadora de pessoa. Só se pode não saber, em suma, em terceira pessoa ou como não-pessoa, de modo que a repetição operada por Ferrari in-opera o precedente enunciado do ex: uma extroversão que faz o significado girar em falso, mostrando a sua falsidade.

5. Em uma carta a Bengt Oldenburg datada de junho de 1977, Ferrari parece esboçar as linhas de uma resistência como pensamento do exterior, como um exílio ou confim: um pensamento alheio à estrutura paradigmática, disjuntiva, que regula dicotomias como arte/vida, estética/ética, dentro/fora etc.

Estuve este fin de semana en Iguazú (Foz) para renovar la visa [...]. Las cataratas desprendían un humo blanco que parecía la corporización de furiosos pensamientos, angustias, de quién se cae de tan alto al torbellino que se ve abajo. Esas gotitas de pensamientos, el aire azul (aquí no se ve el azul del cielo de BAires [sic] aunque seas Rockefeller) y el arco iris, medio cubrían la costa argentina, roja, como el Viejo Toro que me estoy tomando. [...] Pero mientras estaba allá (medio rengo pues me torcí la pata derecha tontamente levantando no se qué cosa del piso del taller, tengo las tabas medio herrumbradas por la pegajosa humedad de Santos y por ese sudor que a veces brota para adentro) con la rodilla envuelta en una larga venda que me recordaba la tumba de Tutankamón $[\ldots]$ aproveché para mandarles tarjetas con cataratas al dorso a media humanidad. Crucé al Paraguay también: vaya tranquilo y goce de la seguridad del Paraguay, me dijeron en guaraní en la aduana.

Estoy trabajando fuerte, me paso el día soldando alambre en complejas e intricadas formas que parecen reflejar la suma de hechos palabras sensaciones que vivimos en estos últimos años. Les mandaré fotos. Si no pudiera hacer estas transfusiones de pequeñas muertes a los alambres de inoxidable, estaría con todo el cuerpo como la rodilla de Tutankamón. Pero gracias al arte, en serio les digo, en general me siento bastante bien y mejor ahora con las noticias. $^{32}$

32. Cf. Carta de León Ferrari a
Bengt Oldenburg (São Paulo, 8 de junho de 1977), Fundación Augusto y León Ferrari - Arte y Acervo.
Os pensamentos furiosos e as angústias de quem cai, distantes do formalismo, das palavras de ordem e da organicidade revolucionária, vigorosa e combativa, materializam-se, aqui, com um corpo frágil, imaterial, dado à suspensão: uma fumaça branca; pequenas gotas, como numa aparição bem situada do 
vapor que Tony Oursler usaria em A máquina-influência (2000), pesquisa de criação do vazio que se apoia na força da repetição - as imagens projetadas no vapor não param de falar - para desdobrar um pensamento da disseminação provavelmente inaugurado em 1919 por Marcel Duchamp com 50cc of Paris Air, e que encontraria suas próprias condições de originalidade também nas experiências subterrâneas de Hélio Oiticica e, ainda, nas liquefações de uma comunidade por vir como as encenadas por Lygia Clark em Baba antropofágica ${ }^{33}$. Essa figura do informe é o que Ferrari vê na fronteira, desse modo imprecisa, da Foz, espaço onde a força prevalecente é mesmo a da vazão, isto é, a força de um esvaziamento que corre sem fim, de um ausentamento insistente, de modo que o que se chama Argentina, agora, como uma sorte de significante vazio ou flutuante, abstrai-se, por trás do véu de gotas de pensamentos, ar azul e arco-íris, como uma linha vermelha, logo comparada ao vinho tinto, e não, como se poderia esperar, ao sangue dos mortos ou a qualquer bandeira; assim como abstraem-se as pequenas mortes, qual transfusões ou traduções, em arames inoxidáveis que, soldados, liberam o fluxo, a passagem, a negatividade do pensamento, que de outra maneira reduzir-se-ia ao engessamento. Nesse sentido, a carta de Ferrari, ou melhor, o pensamento que ela dá a ver parece participar daquilo que Jacques Rancière denomina "el paradigma estético de la nueva comunidad, la de los hombres libres e iguales en su misma vida sensible" 34 . Segundo Rancière, tal paradigma estético - absolutamente não-autonômico - " tiende a cerrar a esta comunidad todos los caminos por los cuales suele procurarse alcanzar una meta" ${ }^{\prime 35}$, e uma de suas expressões mais potentes pode ser encontrada na greve geral:

[...] la expresión consumada de la colectividad obrera combatiente se llamará huelga general, equivalencia ejemplar de la acción estratégica y la inacción radical. La revolución científica marxista quiso, por cierto, terminar con las ensoñaciones obreras como con los programas utópicos. Pero al oponerles los efectos del desarrollo real de la sociedad, sometía una vez más los fines y los medios de la acción al movimiento de la vida, a riesgo de descubrir que lo propio de ese movimiento es no querer nada y no autorizar la prevalencia de ninguna estrategia. [...] La revolución social es hija de la revolución estética, y para negar esa filiación no pudo sino transformar en policía de excepción una voluntad estratégica que había perdido su mundo. ${ }^{36}$

Sinal dessa inação radical que caracteriza o movimento da vida é também o modo como se dá a elaboração do trabalho de Ferrari. Sua intensa dedicação a soldar arames é uma estratégia depuradora, em certo sentido sabática, assumida diante da
33. Cf. ANTELO, Raul. "Institucionalização e disseminação". Crítica Cultural, 2016, p. 13-27.

34. RANCIÈRE, Jacques.

Aisthesis, 2013, p. 15. Também aqui se mantém a tradução do original disponível.

35. Ibidem, p. 15.

36. Ibidem, p. 16. 
37. Cf. FERRARI, León

(Ed.). Augusto C. Ferrari (18711970), 2003.

38. Cf. GIUNTA, Andrea. Escribir las imágenes, 2011.

39. "Mas entrar em sua obra é como ingressar nesses palácios em que há leões de pedra (ou gesso) na porta principal. Porque já de início nos deparamos com dois Leões (Ferraris): um, claramente figurativo, através de colagens dá a sua obra um sentido político ou uma alusão à religião; o outro, baseado na escrita como grafismo abstrato, prima pelo registro sensível". NOÉ, Luis Felipe. "Visita a León Ferrari”, 2006, p. 31. violência e dos vários traumas vividos. Um meio sem fim que constrói esculturas certamente complexas, nas quais sobrevive a soma imensurável de acontecimentos, palavras e sensações (incluindo as rememorações do pai, Augusto César Ferrari, nascido na Itália, arquiteto de igrejas, fotógrafo e pintor de panoramas que preparavam, em chave realista e popular, as traumáticas ambientações e instalações contemporâneas $\left.{ }^{37}\right)$. Assim, numa coincidência silenciosa de atividade e passividade (como coincidem, nesse sentido, os interiores intranscendentes pintados por Juan Pablo Renzi, as paisagens pintadas por Pablo Suárez, os céus pintados por Oscar Bony e as cenas de Luis Felipe Noé, na segunda metade dos anos 1970, quando muitos realizaram esse retorno às "práticas artísticas", após a dissolução do horizonte utópico revolucionário ${ }^{38}$ ), uma vez que recebem as transfusões dessas pequenas mortes, esses arames, entre linhas verticais, horizontais e oblíquas, contaminam-se com um sentido obliterado pela leitura mais consensual, autonomista, que tende a identificar nas esculturas a vertente "estética", a "arte abstrata" de León Ferrari, focada especialmente em aspectos formais e por isso despreocupada de compromissos políticos ou éticos: uma arte oposta, portanto, à sua "outra arte", ao "outro León", "político". E por isso, nesse movimento da vida, não deixa de ser notável o fato de Ferrari voltar à imagem da múmia de Tutankamón ao referir-se à liberdade que então sentia fazendo essas intrincadas formas: como se com elas Ferrari pudesse desatar-se do alcance de um arcaico dispositivo cujo propósito se cumpriria sempre na forma de uma polícia de exceção, ao produzir a separação da vida em dois corpos imunes, neste caso, a separação de León em dois "Leões" ${ }^{39}$, um dos quais seria, por assim dizer, doméstico.

6. A extroversão que situa León Ferrari no confim do horizonte da pessoa - não contra ela, mas a contrastando pelo alheamento que bloqueia seus efeitos - pode ser seguida em outros registros pouco explorados pela crítica. Um desses registros está nos trabalhos do que ficou conhecido como Taller Laberinto, muito associado ao nome de Ruth Varsavsky. Alicia Barros Castro e León Ferrari conheceram Ruth Varsavsky e Oscar Conti (Oski) em 1953, em Roma. Com os casais de volta a Buenos Aires, entre 1958 e 1959, como se sabe, Ferrari se une como produtor a Fernando Birri para, a partir do quadro homônimo de Oski, realizarem La primera fundación de Buenos Aires. Já Ruth Varsavsky e Alicia Ferrari se juntariam, a partir de 1962, na produção de peças artesanais feitas com chapas de latão, bronze, alumínio, alpaca (liga de cobre, zinco, níquel e prata), etc. Com tais materiais faziam objetos para decoração, molduras para espelhos e retratos, biombos, painéis, móbiles e luminárias. Em 
cena, novamente, a criação de vazios: para "la tarea de decorar el aire", Ruth Varsavsky afirma ter sido influenciada tanto pelos móbiles de Calder, que pôde ver no Museu de Arte Moderna de Paris, quanto pelo mundo infantil, como ilustradora de livros e revistas $^{40}$. O golpe de 1976 separaria momentaneamente as duas mulheres e impediria o Taller Laberinto de seguir em Buenos Aires como um espaço de experimentação.

É muito significativo, portanto, que em um caderno de notas de 1977 - que segue até começos de $1978^{41}$ - Ferrari faça não só esboços para suas esculturas de arame - como as versões de Mujer, pensada como artefato silbante, como seriam Berimbau e Percanta -, mas também, às vezes na mesma página e com grande semelhança nos traços dos desenhos, estudos para luminárias, além de planos para cinzeiros, caixas para clipes de papel, estojos para lápis e canetas, porta-cartões, etc. Que algumas das esculturas esboçadas (sobretudo os prismas) sejam pensadas e descritas como jaulas só faz reafirmar que a disjunção entre arte abstrata e arte política, ou entre estética e ética, no trabalho de Ferrari, apenas pode ser produzida por força da obliteração de uma das "partes"; obliteração essa que, ao mesmo tempo, produz a ideia de que há partes que podem ser separadas. O que Ferrari faz é transitar pelas rugosidades do que Andrea Giunta chamou de terceira zona, um espaço-tempo com o qual sempre se encena uma in-ação, uma in-existência. Nesse espaço-tempo singular-plural, desenho, escritura, escultura, colagem, música seus trabalhos coincidem numa margem crítica e sempre móvel, na qual o pensamento da escrita toca o pensamento do desenho, e o pensamento da escultura, e o pensamento da música, e o da colagem, e o da vida, do corpo, do sensível, o pensamento do pensamento, enfim ${ }^{42}$.

Nesse sentido podem ser lidas as páginas do caderno de 1977. Como espaço-tempo singular-plural em uma trama mais extensa que envolve, isto é, que dá a ver o comum. Instância em que convivem fazeres, pensamentos que se posicionam lado a lado, não hierarquicamente. A arte não se sobrepõe à decoração ou ao que se nomeia design. $\mathrm{O}$ que parece exigir que se pense a arte a partir de lugares que em princípio seriam distintos da arte, ou melhor, que se pense a arte pelo que cairia fora: não por aquilo que não seria arte e sim pelo que seria alheio ao limite da arte, ou ao limite entre as artes. Pensar a arte seria assim acolher esse alheamento a respeito da arte. E quem sabe pensar que a arte se faz a si mesma ao desfazer-se de si e do que a faz ser a mesma: ao des-fazer-se. Bruxinhas, borboletas, flores, sóis, luas, estrelas, galos, corujas, pavões, pássaros, rostos, linhas retas, formas curvas: tal a heterogeneidade das figuras que surgiam recortadas, montadas, esmaltadas nas produções do Taller Laberinto - algumas desenhadas por Oski -, pensadas para adornar
40. Cf. FERRARI, Alicia; VARSAVSKY, Ruth. Taller Laberinto, 2009.

41. Nesse caderno, mais de uma vez Ferrari se equivoca no registro do ano, escrevendo 1976 no lugar de 1977 . O que pode ser apenas uma desatenção também permite supor que se trata do retorno de uma forte marca (por certo, ainda muito recente), como uma cadeia complexa de sentidos que teria como possível núcleo significante o ano 1976. O caderno também faz parte da Fundación Augusto y León Ferrari Arte y Acervo.

42. " [...] el pensamiento siempre es ante todo un pensamiento de lo pensable, un pensamiento que modifica lo pensable al acoger lo que era impensable". RANCIÈRE, Jacques. Aisthesis, 2013, p. 12. 
43. Cf. FERRARI, Alicia; VARSAVSKY, Ruth. Taller Laberinto, 2009.
44. RANCIÈRE, Jacques. Aisthesis, 2013, p. 162. as casas. Como nos estudos de Ferrari para lâmpadas, materiais de escritório, para esculturas, trata-se de um sentido de decoração não assimilável ao consumo de luxo ou supérfluos, mas sim incorporado à vida impessoal ou comum. Um sentido que se pode encontrar num galo de latão mexicano como o trazido por Oski, de presente para Ruth, ao fim de uma de suas viagens ${ }^{43}$; sentido arcaico, portanto, anacrônico, fluido como o desejo, e por isso já presente em outros lugares: como em Paris, no início do século XX, em trabalhos de René Lalique, célebre por suas joias e outros objetos de motivos não muito distantes daqueles que apareciam nas peças latino-americanas do Taller Laberinto.

Las joyas de Lalique tal vez solo sean llevadas por mujeres de la buena sociedad. Pero ponen en el adorno de estas el signo de la igualdad. Un artesano las ha hecho como composiciones pictóricas, ignorando la jerarquía entre bellas artes y artes aplicadas. Esas composiciones pictóricas no están destinadas, como los cuadros de caballete, a decorar los salones de aquellas elegantes; su finalidad es incorporarse a la vida de estas, para acompañar sus manifestaciones. Y si son valiosas es por la parte de su propia vida, de su propio pensamiento que el artesano ha incorporado a ellas. Ahora bien, esa vida misma está hecha de la emoción que él ha sentido frente a la vida impersonal de las flores, insectos o paisajes cuyas formas estilizan sus piedras. Lo que brilla sobre el pecho de la mujer de mundo es, por lo tanto, esa vida impersonal, igualitaria, y no la marca de su clase. El valor de su alhaja no la dan ya el tamaño o los quilates del diamante, sino la manifestación singular de la gran vida anónima que han compuesto el pensamiento y las manos del artesano. [...] La elegante lleva en su adorno la igualdad de las artes y la de sus materiales. [...] No es sino una expresión singular de la vida impersonal. ${ }^{44}$

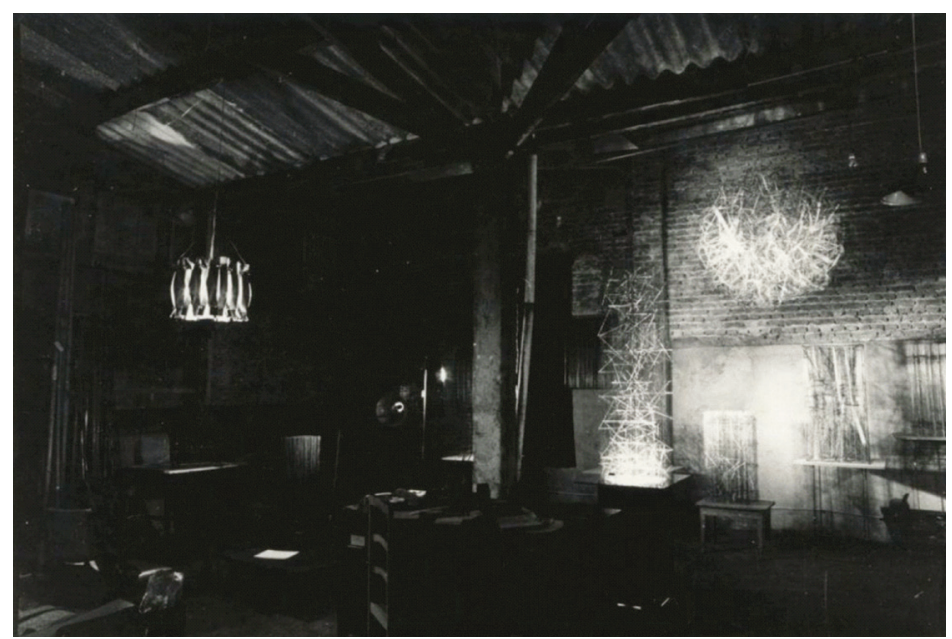

Fig. 2: Taller na Rua Amália de Noronha, Sáo Paulo, 1982. $\mathrm{Na}$ imagem, uma luminária e esculturas iluminadas. Fundación Augusto y León Ferrari - Arte y Acervo 
7. Esculturas, jaulas, luminárias, escritas, desenhos: o que parece caracterizar esse labirinto é antes de tudo a linha. E com a linha, a letra, o leito, a trama. De fato, um taller laberinto, uma oficina do enredo, da urdidura, do tecido, na medida em que um labirinto pode ser compreendido também como bordado de bastidor, no qual o pano destinado ao artesanato é trabalhado no desfiar de seus fios interpolados, onde se criam vazios. A essa feitura - que parece desdobrar-se na própria fatura de Ferrari - igualmente se costuma dar o nome de crivo - de cribrum: joeira, peneira, ciranda, um corpo qualquer, crivado -, o mesmo significante escolhido por Deleuze como condição para um acontecimento:

Um acontecimento não é somente "um homem é esmagado": a grande pirâmide é um acontecimento, e sua duração por 1 hora, 30 minutos, 5 minutos..., uma passagem da Natureza ou uma passagem de Deus, uma visão de Deus. Quais são as condições de um acontecimento, para que tudo seja acontecimento? O acontecimento produz-se em um caos, em uma multiplicidade caótica, com a condição de que intervenha uma espécie de crivo ${ }^{45}$.

A arte parece propor uma forma de escritura singular, mas não avessa à filosofia: trata-se de uma espécie de queda que desse modo intervém na criação de um contexto, ou seja, trata-se de situar-se sem a priori, de com a linguagem criar um texto e suas condições de emergência. Esse sentido móvel da linha, da letra, do texto, labirinto aberto, por assim dizer, ao que passa, franqueia uma produtiva leitura para o trabalho exílico de Ferrari. Ele está, por certo, nos estudos que remontam ao Taller Laberinto, mas se estende às séries de desenhos e colagens com letraset em que Ferrari expõe a uma forma de contenda - ora mais amorosa, sedutora, ora mais combativa, irônica - a operatividade do poder que embasa a codificação e decodificação de signos; e se estende ainda à série Projetos, aos Planos, às heliografias, trabalhos nos quais se percebe um uso lúdico dos códigos normalizados e mecanicamente produzidos, espelhados com diferença por meio da construção desses espaços fechados e inabitáveis, muitos povoados por multidões que se aglomeram, mas crivados por um vazio central (como em Planta, Proyecto, Cuadrado, Espectadores, Espiral, Autopista del Sur, Round Point 1, Round Point $2^{46}$, do início dos anos 1980); e se estende, ademais, aos diversos mimetismos, a partir de 1986, encenados com colagens de figuras, objetos e textos (como sua série de Mimetismos escritos, já do final de $1990^{47}$ ). E quem sabe uma das inflexões mais notáveis dessa série possa ser lida na imaterialidade dos escritos en el aire ${ }^{48}$ que são as linhas, as grafias, os desenhos de suas esculturas sonoras. Tal é a cadência do pensamento de León Ferrari: criadora de espaçamentos, de aberturas. O silêncio, nesse sentido,
45. DELEUZE, Gilles. A dobra, 2000, p. 132.

46. Estas séries citadas, algumas publicadas em Homens (1984) e Imagens (1989), estão reunidas em FERRARI, León. Plano y Papeles (1979-1982), 2004.

47. Parte desses trabalhos pode ser conferida em FERRARI, León. La bondadosa crueldad, 2000.

48. Título de um livro publicado em 1964 com desenhos de León Ferrari e poemas de Rafael Alberti. 
49. Palabras ajenas é o título do livro editado por Ferrari em 1967. Trata-se de uma extensa montagem de citações, com cerca de 120 personagens ligados a diferentes tempos da civilização ocidental e cristã: o Antigo Testamento, a Alemanha nazista, o imperialismo norteamericano. Ademais, trechos de agências de notícias, periódicos e de diversos autores, entre eles Sade. Ferrari concebeu o texto para ser encenado, uma peça sem começo nem fim: "ya habrá empezado cuando el primer espectador entre en la sala, y sólo terminará cuando el último se haya ido". Cf. FERRARI, León. Palabras ajenas, 2008. Adaptado, o texto teve uma montagem de Leopold Maler em 1968, estreando no Arts Laboratory de Londres com o título de Listen Here Now. A New Concert for Four Voices and a Soft Drum. é uma das possibilidades levadas adiante com sua música: não uma "parte" dela, nem a sua negação. Em Sin título, da série Códigos, encontra-se uma das possíveis excrituras desse sentido vaporoso, vazante, capaz de drenar significados cristalizados. E trabalhos como Berimbau, como Percanta e mesmo o nome da editora que Ferrari cria - Edições Exu - mostram um sentido de texto, um texto por vir, se assim se quiser, afim a uma noção de arquivo em que os afetos jogam sempre um papel central.
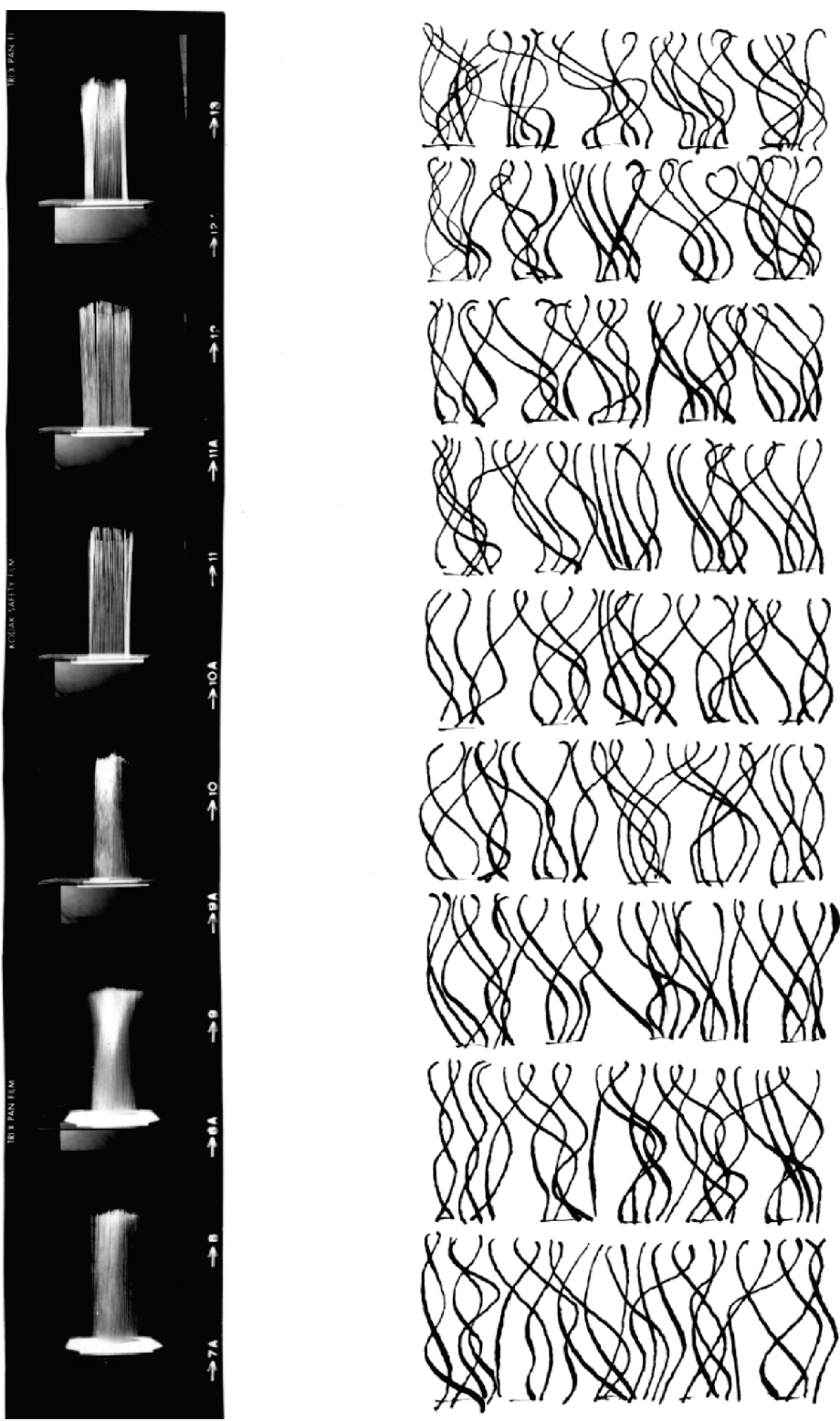

Fig. 3: León Ferrari, Sin título, 1979 (32 x 21,5 cm). Fundación Augusto y León Ferrari Arte y Acervo.

Berimbau (do quimbundo mbirimbau) é outra das muitas $p a$ lavras alheias que Ferrari escolhe para compor seus trabalhos ${ }^{49}$. Esta nomeia uma escultura de grande altura, composta por cem barras de diferentes diâmetros, unidas em sua extremidade 
inferior a uma base comum, numa espécie de pêndulo invertido, e que foi apresentada na exposição de Arte Lúdica no Museu de Arte de São Paulo, em 1979. Inspirada no instrumento utilizado nas rodas de capoeira, sua concepção valoriza os contornos de um pensamento da impessoalidade: a criação de sons, de silvos, de cantos, com a passagem do vento ou dos corpos através dos vazios entre as barras metálicas. O silêncio e o espaçamento: o vazio entre uma nota e outra, entre um timbre e outro, entre cada uma das cordas ou linhas dispostas e à disposição dos ouvintes que, à escuta, devem tocá-las, criando com isso o que vem a ser um instrumento, e igualmente o que Ferrari pensa como uma espécie de escultura ou de desenho no ar, isto é, criando a imaterialidade de uma força singular-plural ${ }^{50}$. Berimbau é uma escultura que dança uma "música não figurativa", como definiu Ferrari, mas também uma escultura que se lê, ou nas inscrições dos desenhos no ar ou em suas traduções, como no texto Flasharte I: Berimbau: artefato para desenhar sons, escrito por Ferrari em 1979 e reproduzido para ser enviado por correio. Nesse texto coexistem leveza e luta, entrega e resistência, outros modos da inação como estratégia, do movimento da vida ou do acontecimento que, impessoal, "coincide con una emisión de singularidades que no tienen la forma aperceptiva del yo ni la transcendental de la conciencia" ${ }^{\circ 1}$.

Tal emissão de singularidades corresponderia às carícias, aos afetos, aos encontros de tempos heterogêneos, de linhas de deslocamento e concatenação ${ }^{52}$. As esculturas sonoras que se seguiram a Berimbau receberam outro nome significativo: Percanta, "palavra do lunfardo de Buenos Aires que significa 'menina, moça, garota", explica Ferrari ${ }^{53}$. Com efeito, o léxico do lunfardo registra esse sentido: "Mujer, considerada desde el punto de vista amatorio"; mas acrescenta a ele uma deriva das mais notáveis: "Probablemente, del esp. percal: tela de algodón, muy empleada en la indumentaria femenina" "54. O célebre tango Percal de Homero Expósito, de 1943, abre a passagem de um sentido a outro:

$[\ldots]$ La juventud se fue...
Tu casa ya no está...
Y en el ayer tirados
se han quedado
acobardados
tu percal y mi pasado.
La juventud se fue...
Yo ya no espero más...
Mejor dejar perdidos
los anhelos que no han sido
y el vestido de percal. $[\ldots]^{55}$

Cria-se assim uma sucessão de dobras em que se passa do labirinto à linha, e da linha à letra, e da letra à música, e da
50. “La música contemporánea nos es necesariamente tonal o atonal, no es obligatoriamente electrónica ni se desenvuelve forzosamente en la ultracomplejidad contrapuntística. A veces juega con las convenciones anteriores y a veces las niega. En algunas ocasiones elige circular por los mismos canales que la música del pasado -los conciertos, las representaciones de ópera- y en otras intenta fundar, con ella, nuevas formas de recepción. La música compuesta a partir del siglo XX puede ser casi de cualquier manera pero siempre responde a una especie de vacío inicial. En todo caso, es la primera en la historia para la que no hay una estética fijada de antemano; es la que inaugura la necesidad de, antes de existir, preguntarse $-\mathrm{y}$ responder con la obra, es claro- acerca de su estética. Y es la única que partió, aunque haya sido para no tener en cuenta ese punto de partida, de la posibilidad de no ser música". FISCHERMAN, Diego. Después de la música, 2011, p. 29.

51. ESPOSITO, Roberto. Tercera persona, 2009, p. 206.

52. Ibidem, p. 214.

53. Apud. GIUNTA, Andrea. (ed.). León Ferrari: retrospectiva, 2006, p. 177.

54. GOBELLO, José. Dicionario Lunfardo y de otros términos antiguos y modernos usuales en Buenos Aires, 1989, p. 164.

55. Agradeço a referência a Gastón Cosentino. A letra e a música são encontradas facilmente na web. 
56. ESPOSITO, Roberto. Tercera persona, 2009, p. 205-206. música ao corpo, e do corpo ao tecido, e do tecido à linha, e isso não linearmente, mas sim em trama, quer dizer, com texto, por passagens que coexistem, se disseminam, se aproximam e distanciam em modulações, tonalidades, vazios, línguas, linguagens, num contínuo flerte, como num jogo de sedução do pensamento. Poderia ser dito que o trabalho de Ferrari percanta, no caso de se escutar essa palavra num português quem sabe alheio à língua portuguesa: composta pelo prefixo latino per - movimento através de, passagem por, mas também proximidade, intensidade - e o verbo cantar conjugado na terceira pessoa: ele, ela, um qualquer percanta: quando se busca ou é através do canto, e quando um cantar se canta cantando o outro. Eis, enfim, uma forma de extroversão que se situa no confim do horizonte da pessoa; uma suspensão ou bloqueio dos seus efeitos a partir da identificação com o acontecimento, instância em que a causa concorda com seu próprio efeito e o agente é uma mesma coisa com seu próprio paciente $e^{56}$. Uma saída que passa pela existência da vida, na medida em que ela insiste, escapa ao controle e exatamente assim constitui uma singularidade, vale dizer, uma forma de resistência, ainda. Uma terceira pessoa percanta: seduz, seduzida.

8. Na mostra Taller Ferrari no Centro Cultural de la Memoria Haroldo Conti, os visitantes podiam assistir ao documentário de Rubén Guzmán e Andrés Duprat Civilización (2012), um dos últimos realizados com León Ferrari ainda vivo. No filme, entre textos de Ferrari narrados em off, surge uma afirmação que parece reivindicar um espaço-tempo dedicado à luta pelos Direitos Humanos, ao mesmo tempo em que desloca o consenso a respeito do que se diz com o nome democracia, tantas vezes reafirmada como inseparável desses mesmos direitos, que todavia são sustentados numa espécie de cegueira quanto à antinomia que há na justaposição dos dois termos. "La democracia empieza en el culo: que cada uno haga lo que quiera con su hueco", afirma Ferrari. Em outras palavras: cada um com seu desejo - seu oco, seu eco -, com seu vazio. Quem sabe uma possível ética da vida vivente passe, de alguma maneira, por essa singular forma de democracia comunitária, ou mesmo comunista, à qual responderia a justiça de uma inaudita politica comum, ou de um direito em comum, algo que se insinua no pensamento, ainda como desafio.

\section{Referências}

ANTELO, Raul. "El futuro fabuloso, la forma formante y el pozo de Babel". In: Imágenes de América Latina. Comentarios: Maximiliano Crespi. Buenos Aires: EDUNTREF, 2014. 
. "Institucionalização e disseminação". Crítica Cultural,

Palhoça, v. 11, p. 13-27, julho 2016. Disponível em: <http://

www.portaldeperiodicos.unisul.br/index.php/Critica_Cultural/

article/view/3765>. Acesso em: 19 abril 2017.

BENVENISTE, Émile. "Estrutura das relações de pessoa no verbo". In: Problemas de linguística geral. Tradução: Maria da Glória Novak e Luiza Neri. São Paulo: Editora Nacional; EDUSP, 1976.

BURUCÚA, José Emilio; KWIATKOWSKI, Nicolás. “Un terror, dos lugares, ¿qué memoria? Reflexiones acerca de dos espacios para la memoria en el Cono Sur". Caiana. Revista electrónica de Historia del Arte y Cultura Visual del Centro Argentino de Investigadores de Arte (CALA), n. 1, jul. 2012, p. 1-9.

DELEUZE, Gilles. A dobra: Leibniz e o barroco. Tradução: Luiz B. L. Orlandi. 2. ed. Campinas: Papirus, 2000.

DELGADO, Honorio. "La persona humana desde el punto de vista psicológico”. Actas del Primer Congreso Nacional de Filosofía [Mendoza, 1949], Universidad Nacional de Cuyo, Buenos Aires, 1950, tomo I, p. 270-280.

DERISI, Octavio Nicolás. "Fenomenología y ontología de la persona". Actas del Primer Congreso Nacional de Filosofía [Mendoza, 1949], Universidad Nacional de Cuyo, Buenos Aires, 1950, tomo I, p. 281-299.

ESPOSITO, Roberto. Tercera persona: política de la vida y filosofía de lo impersonal. Traducción: Carlo R. Molinari Marotto. Buenos Aires: Amorrortu, 2009..

FERRARI, León (Ed.). Augusto C. Ferrari (1871-1970): cuadros, panoramas, iglesias y fotografías. Buenos Aires: Ediciones Licopodio, 2003.

La bondadosa crueldad: poemas e collages. Buenos Aires:

Editorial Argonauta, 2000. Planos y Papeles (1979-1982). Buenos Aires: Ediciones Licopodio, 2004. . Palabras ajenas. Buenos Aires: Falbo, 2008.

FERRARI, Alicia; VARSAVSKY, Ruth. Taller Laberinto. Buenos Aires: Licopodio, 2009.

FISCHERMAN, Diego. Después de la música: el siglo XX y más allá. Buenos Aires: Eterna Cadencia, 2011.

GIORGI, Artur de Vargas. "A primeira fundação de Buenos Aires, ainda”. PÓS: Revista do Programa de Pós-graduação 
em Artes da EBA/UFMG, Belo Horizonte, 2016, p. 62-73, v. 6, n. 12 .

GIUNTA, Andrea. León Ferrari: Retrospectiva. Obras 19542006. São Paulo: Cosac Naify; Imprensa Oficial, 2006. - ¿Cuándo empieza el arte contemporáneo? $1 \mathrm{ed}$. Ciudad Autónoma de Buenos Aires: Fundación arteBA, 2014. . Escribir las imágenes: ensayos sobre arte argentino y latinoamericano. Buenos Aires: Siglo XXI, 2011.

GOBELLO, José. Dicionario Lunfardo y de otros términos antiguos y modernos usuales en Buenos Aires. Buenos Aires: Pena Lillo Editor, 1989.

HARTMANN, Nicolai. "El 'ethos' de la personalidad". Actas del Primer Congreso Nacional de Filosofía [Mendoza, 1949], Universidad Nacional de Cuyo, Buenos Aires, 1950, tomo I, p. 300-315.

LINK, Daniel. "León Ferrari: la experiencia exterior". In: León Ferrari - Brailles y relecturas de la Biblia. Curaduría: Florencia Battiti. Buenos Aires: MALBA, 2012.

LORENZ, Federico. "La ESMA, un espacio en construcción: Estado y actores sociales en un sitio de memoria". In: BIRLE, Peter [et. al.]. Memorias urbanas en diálogo: Berlín y Buenos Aires. Buenos Aires: Buenos Libros, 2010, p. 157-176 [p. 165/167].

NOÉ, Luis Felipe. "Visita a León Ferrari”. Tradução: Ana Paula Gomes. In: GIUNTA, Andrea (Ed.). León Ferrari: Retrospectiva. Obras 1954-2006. São Paulo: Cosac Naify; Imprensa Oficial, p. 31-41.

PAREYSON, Luigi. "Sobre el concepto de persona". Actas del Primer Congreso Nacional de Filosofía [Mendoza, 1949], Universidad Nacional de Cuyo, Buenos Aires, 1950, tomo II, p. 1079-1083. . "La filosofía italiana contemporánea". Actas del Primer Congreso Nacional de Filosofía [Mendoza, 1949], Universidad Nacional de Cuyo, Buenos Aires, 1950, tomo I, p. 480-492.

RANCIÈRE, Jacques. Aisthesis: escenas del régimen estético del arte. Traducción: Horacio Pons. Buenos Aires: Manantial, 2013.

ROMANDINI, Fabián Ludueña. A comunidade dos espectros. I. Antropotecnia. Tradução: Alexandre Nodari e Leonardo D’Ávila de Oliveira. Desterro, Florianópolis: Cultura e Barbárie, 2012. 
. "Ultra-historia del exilio: una genealogía de la

Modernidad”. In: ROMANDINI, Fabián Ludueña;

BURELLO, Marcelo; TAUB, Emmanuel. Politicas del exilio:

orígenes y vigencia de un concepto. Caseros: EDUNTREF, 2011, p. 121-135.

SANTAMARÍA, Eduardo Carrero. "La catedral, el santo y el rey. Alfonso IV de Portugal, san Vicente mártir y la capilla mayor de la sé de Lisboa". In: ESPAÑOL, Francesca; FITÉ, Francesc (Eds.). Hagiografia peninsular en els segles medievals. Lleida: Universitat de Lleida, 2008, p. 73-92.

SARLO, Beatriz. Tiempo pasado: cultura de la memoria y giro subjetivo. Buenos Aires: Siglo XXI, 2005 (Colección Sociología y Política). 